\title{
Selective Toxicity of the Entomopathogenic Fungus Beauveria bassiana (Balsamo) to the Two Spotted Spider Mite Tetranychus urticae Koch and the Predator Stethorus gilvifrons (Muls.)
}

\author{
G. A. EL Kady ${ }^{*}$, S. M. M. Ismail", M. S. Salman ${ }^{* *}$ and Y. M. Ahmed \\ "Plant Protection Dept., Faculty of Agricultural, Suez Canal University, Ismailia, Egypt \\ ${ }^{* *}$ Plant Protection, Agriculture Research Station, Ismailia, Egypt
}

\begin{abstract}
The selective toxicity efficacy of entomopathogenic Beauveria bassiana (Balsamo) fungus was evaluated against the two spotted spider mite Tetranychus urticae Koch and its predator Stethorus gilvifrons (Muls) under laboratory condition. The tested B. bassiana strain had been brought from Plant Protection Institute, Agricultural Research Center, Jokioinen, Finland. The activation of B. bassiana was carried out using Tenebrio molitor (L.) larvae as a bait insect. Conidia of growing fungus were extracted and counting of spores was computed. Five concentrations of the conidial suspension were prepared $\left(3.92 \times 10^{4}, 3.92 \times 10^{5}, 3.92 \times 10^{6}, 3.92 \times 10^{7}\right.$ and $3.92 \times 10^{8}$ spores $\left./ \mathrm{ml}\right)$. Results revealed that the mortality rates for both adult females of the mite $T$. urticae and the predator S. gilvifrons infected by B. bassiana were positively correlated with stranded stage concentration and time dependent. There was a latent eight-day period between infestation and mortality achievement in both tested organisms. On the eighth day, $\mathrm{LC}_{50}$ values of B. bassiana were $2.702 \times 10^{5}$ and $2.208 \times 10^{12}$ spores $/ \mathrm{ml}$ for adult females of $T$. urticae and $2^{\text {nd }}$ instar larval stage of $S$. gilvifrons, respectively. Such selective toxicity was also noted at LC 90 level where the values were $6.1987 \times 10^{10}$ and $2.839 \times 10^{17}$ for adult females of T. urticae and $2^{\text {nd }}$ instar larvae of $S$. gilvifrons respectively. These results showed that the entomopathogenic fungus $B$. bassiana has a potent selective toxicity against adult females of $T$. urticae compared with second instar larvae of $S$. gilvifrons.
\end{abstract}

Key Words: Tetranychus urticae, Stethorus gilvifrons, Beauveria bassiana, Biological control.

\section{INTRODUCTION}

The fungus Beauveria bassiana (Balsamo) was firstly recognized as a disease-causing organism by Bassi (1835) and has been used as a biological control agent for about 100 years (De Bach 1948). It is nonspecific entomogenous fungus with a broad geographical distribution (Tanada 1953; Leatherdale 1970; Kenneth et al. 1971). In Britain, Dresner (1949) recorded the fungus infecting and causing mortality of Tetranychus urticae in the field. He also found that $0.5 \%$ spore preparation of $B$. bassiana was effective against $T$. urticae on beans. The experiments were carried out in July in very favorable weather for infection and development of the fungus, at $91.3 \%$ R.H. and $23.3^{\circ} \mathrm{C}$ in the morning.

In Egypt, Yousri, 1994 and 1999 studied the pathogenicity of $B$. bassiana against $T$. urticae at various temperatures. On the other hand, several studies indicated that all species of Stethorus weise are varacious obligate spider mite predators (Helle \& Sabelis, 1985; Sarhan et al. 1989a\&b and Rott \& Ponsonby, 2000) with high capabilities to control spider mites both in open fields and greenhouses (Congdon et al., 1993). On the other hand, the toxicity of some bio-insecticides such as Spinosad and Vertimec and the predation response of some preditors on T. urticae were investigated (El-Basha et al., 2005; Raudonis, 2006 and El-Kady et al. 2007).

The present study evaluated the effect of $B$. bassiana on adult stage of the two-spotted spider mite T. urticae and its predator S. gilvifrons in order to assess the selective toxicity of the fungus to be implemented in IPM of T. urticae.

\section{MATERIALS AND METHODS}

The techniques used for laboratory assays were similar to those used by Tanada et al. (1953), Dunn \& MacLeod (1963); Yevlakhova \& Shvetsova (1965); Roberts \& Yendol (1971); Vanninen \& Hokkanen (1988) and Yousri (1994).

\section{Pathogenic:}

B. bassiana, a laboratory strain was brought from Plant Protection Institute, Agricultural Research Center, Jokioinen, Finland host organism of the strain benefit.

\section{Activation of the strain:}

The strain of $B$. bassiana was stored in deep freezer and reinoculated regularly every three months using potato dextrose agar (PDA) medium in Plant Protection Lab., Ismailia Agricultural Research Station. The activation was done using Tenebrio molitor L. larvae as a bait insect. Ten larvae were placed in a petri-dish and infected by $B$. bassiana by spraying with the suspension of the spores using manual atomizer (Sigma glass spray unit No. S 3135). The petri-dishes were covered with wetted filter papers to increase the relative humidity then placed at $25^{\circ} \mathrm{C}$ and about $100 \% \mathrm{RH}$. After about seven days, the 
larvae died and the hyphae of the fungus appeared on the upper surfaces of the larvae. The dead larvae were rinsed for three minutes in $0.1 \%$ sodium hypochloride, then thoroughly washed with tap water by placing the larvae in a sieve, then dried by rolling gently on tissue paper. Larvae were then placed in a petri-dish containing a selective medium which allowed $B$. bassiana to grow only without contaminating strains of saprophytic fungi. The petri-dishes were kept at $25^{\circ} \mathrm{C}$ to notice the fungus growth. This activation process was repeated several times to increase the pathogenicity of the tested strain.

\section{Harvesting of spores from agar to prepare the original treatment suspension:}

The spores of growing fungus were harvested by adding a mixture of $100 \mathrm{ml}$ of sterile water $+50 \mu \mathrm{l}$ of tween 20 to each petri-dish to reduce the surface tension of the spores suspension. The spores were harvested from the surface of agar by scraping with spatula into the mixture of water + tween 20 then the crude suspension was collected in sterilized bottle ( $250 \mathrm{ml}$ in size). The glass pearls were added to the bottle and shacked well using a laboratory horizontal shaker to separate the medium, mycelium and spores from each other. The big lumps of mycelium and growth media, were removed from the suspension by using an ordinary tea sieve or muslin cloth.

\section{Preparation of spore suspension:}

Determination of spores concentration was made by using the Burker chamber (hemocyte counter) as follow:

The spores were harvested from the mass culture media of the fungus into sterile water containing $0.05 \%$ tween 20 (surfactant). Dilution was done to facilitate the spores suspension counting. One $\mathrm{ml}$ of initial spores suspension was added to $9 \mathrm{ml}$ of sterile water containing $0.05 \%$ tween 20 and then shacked well. Using 1/100 dilution rate was enough, taking the concentration of the initial suspension into consideration.

A small drop of the final dilution was put into the dish of a Burker counter by using a pasteur pipette. The dish should be full, but the water should not run out of it. A cover slip was carefully placed over the dish, so that the water drop spread over the sets of squares (the counting cells). After at least 2 minutes the spores sediment to the bottom of the counting cell, then the number of spores was counted under amicroscope, in each of the nine squares surrounded by three lines, altogether nine squares in the upper counting cell and nine in the lower counting cell. (NB: the lines of the counter and the number of the counting squares can be differently arranged according to the type of the chamber: some time for example the number of squarer being twelve instead of nine, but the counting principle remains the same). The counting was repeated for four times (4 drops) to obtain a good estimate of the spore concentration.

The spore concentration was calculated by using the following formula:-

$$
\text { No. of spores in suspension }=\mathrm{m} \times 2.5 \times 10^{5} \times \mathrm{d}
$$

Where: $\mathrm{m}=$ mean number of spores per one square, $\mathrm{d}=$ dilution rate.

The volume of the square was usually, at least in Burker chamber, $1 / 4000 \mathrm{ml}$, i.e $2.5 \times 10^{5}$ is used in the formula.

\section{Check of fungal spores viability}

The viability of spore suspension was checked before preparing the final suspension with known concentration. The percentage viability was used in calculating the amount of the original suspension needed to prepare the final suspension. A drop of $50 \mu \mathrm{l}$ from suspension (subjected for spore viability) was added to autoclaved test tubes containing one ml of PDA and mixed well by the help of a vortex-mixer. The tube was corked and incubated at $25{ }^{\circ} \mathrm{C}$ (the optimum temperature for $B$. bassiana growth) for about $20 \mathrm{~h}$. After the incubation period, the counting of spores was made for germinated spores by taking three drops of agar from the tube into a glass-slide and cover them with glasses. A total of 100 spores from each drop, randomly chosen vision fields, then the germinated and non-germinated spores were counted separately. The percentage of germination (= viability) spores was calculated. The proportion of viable spores should be over $85 \%$.

\section{Spraying of fungal suspension on the adult female mites T. urticae:}

This test was carried out by placing 25 adult females on the lower surface of sweet potato discs (one inch in diameter), all discs were placed in petri-dishes on moist cotton wool. Each petri-dish contained four discs as replicates. From the stock suspension which was prepared of known concentration of spores, five concentrations of the conidial suspension by dilution with sterile water were prepared $\left(3.92 \times 10^{4}, 3.92 \times 10^{5}, 3.92 \times 10^{6}, 3.92 \times 10^{7}\right.$, $\left.3.92 \times 10^{8}\right)$. A constant amount $4 \mathrm{ml} /$ petri-dish (4 replicates) was sprayed by a glass manual atomizer (Sigma glass spray unit No. S3135) for each concentration. The control check discs were treated with $4 \mathrm{ml}$ of sterile water mixed with a wetting agent (tween 20). The petri-dishes were incubated for 
12 days under constant temperature $25 \pm 2{ }^{\circ} \mathrm{C}$ and relative humidity approximately $100 \%$. The surviving mites were counted daily and the mortality percentage was calculated. Cumulative percent mortalities were corrected and analyzed as described before (Abbott, 1925 and Finney 1971).

\section{Spraying fungal suspension on the second instar of} larval stage of the predator $S$. gilvifrons:

Fifty moving individuals of the two-spotted spider mite and 10 individuals of second instar larval stage of the tested predator were transferred by the aid of a fine brush onto the sweet potato leaf discs. From the stock suspension, which was prepared of a known concentration of spores, five concentrations of the conidial suspension by dilution with sterile water were prepared. A constant amount of four $\mathrm{ml} /$ petri-dish (4 replicates) was sprayed by a glass manual atomizer (Sigma glass spray unit No. S3135) for each concentration. The control check discs were treated with four $\mathrm{ml}$ of sterile water mixed with a wetting agent (tween 20). The petri-dishes were incubated for eight days under constant temperature $25 \pm 2{ }^{\circ} \mathrm{C}$ and relative humidity approximately $100 \%$. The survivor larvae were counted daily and the percentage mortality was calculated.

Koch's Postulates test was carried out to ensure the positive involvement of the fungus. The cadavertested mites were simply placed on selective agar medium which had been poured on petri-dishes to form a layer of approximately three mm thickness. The composition of this selective medium MacConkey agar and modification as follows:- Distilled water (1 Liter); agar (10 g); glucose (5 g); yeast extract (2 g); chloramphenicol $(50 \mathrm{mg})$; cycloheximide $(200 \mathrm{mg})$ and $1 \mathrm{~g}$ for each Sodium nitrate; $\left(\mathrm{NaNo}_{3}\right)$; magnesium phosphate $\left(\mathrm{MgPO}_{4} .7 \mathrm{H}_{2} \mathrm{O}\right)$; potassium phosphate $\left(\mathrm{KH}_{2} \mathrm{PO}_{4}\right)$; sodium propionate; Oxen gall. (Alves et al., 2002).

The selective medium efficiently prevents the growth of other bacteria and, saprotophic fungi, but allows $B$. bassiana to grow freely.

\section{RESULTS AND DISCUSSION}

\section{Effect of $B$. bassiana on the adult female stage of} the two spotted spider mite $T$. urticae:

The mortality rate of the adult females of the mite $T$. urticae infected by $B$. bassiana increased with increasing concentration of spore inoculum (Tables 1 \& 2). Statistical significance levels between moralities at each spore dilution after eight days from exposure are given in Table 2. The $\mathrm{LC}_{50}$ after eight days of exposure was calculated to be $2.702 \times 10^{5}$ spores $/ \mathrm{ml}$.
After 10 days of exposure at $3.92 \times 10^{6}, 3.92 \times 10^{7}$ and $3.92 \times 10^{8}$ spores $/ \mathrm{ml}$, all the tested mites died. These mortalities were significantly greater than control mortality. All treated mites at the remaining spore concentrations, i.e., $3.92 \times 10^{4}$ and $3.92 \times 10^{5}$ spores $/ \mathrm{mL}^{-1}$, were killed after 12 days (Table 2) and control mortality at this time was significantly lower than treatment mortality. The mortality rates of $T$. urticae infested by $B$. bassiana were in part a function of spore inoculum concentration. More than $10^{4}$ spores $/ \mathrm{ml}$ of $B$. bassiana resulted in significant mortality of $T$. urticae after 10 days, whereas at lower spore concentrations all treated mites were killed after 12 days. Level of mortality between treatments and control in the pathogenicity tests was compared using $X^{2}$ contingency tables (Table 2). The slope was calculated from the computerized probity analysis program is $b=0.239$.

\section{Effect of $B$. bassiana against $S$. gilvifrons:}

The mortality rate of the second instar of larval stage of the predator $S$. gilvifrons infested with the laboratory strain of $B$. bassiana was decreased with decreasing concentration of spore inoculum (Tables 3 \& 4). Statistical significance levels between mortalities at each spore dilution after eight days of exposure are given in table 3 . The $\mathrm{LC}_{50}$ after eight days exposure period resulted in $2.208 \times 10^{12}$ spores $/ \mathrm{ml}$, whereas $\mathrm{LC}_{90}$ after eight days from exposure recorded $2.839 \times 10^{17}$ spores/ml (Table 4).

After 10 days of exposure at $3.92 \times 10^{7}$ mortality recorded $50 \%$, whereas $3.92 \times 10^{8}$ spores $/ \mathrm{ml}$, resulted in $70 \%$. The rest of concentrations resulted in $20 \%$ mortality after 8 days of exposure. That makes the laboratory strain safe to the predator comparing with its effect on the mite at the same concentrations.

The mortality rates of $S$. gilvifrons infested by B. bassiana are in part a function of spore inoculums concentration. More than $10^{7}$ spores $/ \mathrm{ml}$ of $B$. bassiana gave an effective kill of $S$. gilvifrons after 10 days, whereas at lower spore concentrations all treated insects had less effect on the treated insects. Level of mortality between treatments and control in the pathogenicity tests was compared using $X^{2}$ contingency tables (Table 4). The probity line expresses the mortality of the predator $S$. gilvifrons related to $\log$ of the concentration of $B$. bassiana spores. The slope of this line from the computerized probity analysis program (Table 4) is $b=0.251$.

Results of selectivity ratio of $B$. bassiana to adult female of $T$. urticae and the predator $S$. gilvifrons are shown in table 5. It revealed that the mortality 
Table (1): Mortality \% of the adult female of $T$. urticae exposed to a series of spore concentrations of B. bassiana (lab. strain).

\begin{tabular}{ccccccccc}
\hline $\begin{array}{c}\text { Concentration } \\
\text { (Spores No./ ml) }\end{array}$ & \multicolumn{8}{c}{ Days after treatment } \\
\cline { 2 - 8 } & 2 & 3 & 4 & 5 & 6 & 7 & 8 & 10 \\
\hline $3.92 \times 10^{8}$ & 0 & 4 & 12 & 22 & 64 & 82 & 92 & 100 \\
\hline $3.92 \times 10^{7}$ & 0 & 2 & 6 & 8 & 46 & 60 & 68 & 100 \\
\hline $3.92 \times 10^{6}$ & 0 & 0 & 2 & 12 & 38 & 52 & 66 & 100 \\
\hline $3.92 \times 10^{5}$ & 0 & 0 & 2 & 4 & 28 & 42 & 58 & 86 \\
\hline $3.92 \times 10^{4}$ & 0 & 0 & 0 & 6 & 14 & 38 & 48 & 64 \\
\hline Control & 0 & 0 & 0 & 0 & 4 & 6 & 10 & 10 \\
\hline
\end{tabular}

Table (2): Probit analysis data for B. bassiana-treated mites.

\begin{tabular}{ll}
\hline slope $(\mathrm{b})$ & $=0.239$ \\
\hline intercept $(\mathrm{a})$ & $=3.701$ \\
\hline Chi-square & $=10.26\left(\right.$ Tabulated $\left.X^{2}=7.8\right)$ \\
\hline $\mathrm{DF}$ & $=3$ \\
\hline Heterogenecteity factor & $=3.421$ \\
\hline $\mathrm{LC}_{50}$ & $=(2.7019) \times 10^{5} \mathrm{spores} / \mathrm{ml}$ \\
\hline $\mathrm{LC}_{90}$ & $=(6.1987) \times 10^{10} \mathrm{spores} / \mathrm{ml}$ \\
\hline $\mathrm{r}($ Correlation coefficient) & $=0.915($ Tabulated $\mathrm{r}=0.878)$ \\
\hline $\mathrm{P}\left(\right.$ probability of $\left.X^{2}\right)$ & $=0.0165$ \\
\hline
\end{tabular}

Table (3): Mortality percentage of the second instar of larval stage of $S$. gilvifrons exposed to a series of spore concentrations of B. bassiana.

\begin{tabular}{|c|c|c|c|c|c|c|c|c|c|}
\hline \multirow{2}{*}{$\begin{array}{l}\text { Concentration } \\
\text { (Spores No./ ml) }\end{array}$} & \multicolumn{9}{|c|}{ Days after treatment } \\
\hline & 2 & 3 & 4 & 5 & 6 & 7 & 8 & 9 & 10 \\
\hline $3.92 \times 10^{8}$ & 0 & 5 & 5 & 10 & 15 & 25 & 30 & 45 & 70 \\
\hline $3.92 \times 10^{7}$ & 0 & 5 & 10 & 10 & 20 & 25 & 25 & 40 & 50 \\
\hline $3.92 \times 10^{6}$ & 0 & 0 & 5 & 5 & 10 & 20 & 20 & 30 & 40 \\
\hline $3.92 \times 10^{5}$ & 0 & 0 & 0 & 10 & 10 & 20 & 20 & 25 & 45 \\
\hline $3.92 \times 10^{4}$ & 0 & 0 & 0 & 0 & 5 & 15 & 15 & 20 & 40 \\
\hline Control & 0 & 0 & 0 & 0 & 5 & 10 & 15 & 25 & 30 \\
\hline
\end{tabular}

Table (4): Probity analysis data for B. bassianatreated predator.

\begin{tabular}{ll}
\hline slope $(\mathrm{b})$ & $=0.251$ \\
\hline intercept (a) & $=1.9$ \\
\hline Chi-square & $=0.198 \quad$ (Tabulated $=6)$ \\
\hline $\mathrm{DF}$ & $=3$ \\
\hline Heterogenecteity factor & $=9.9$ \\
\hline $\mathrm{LC}_{50}$ & $=(2.208) \times 10^{12} \mathrm{spores} / \mathrm{ml}$ \\
\hline $\mathrm{LC}_{90}$ & $=(2.839) \times 10^{17} \mathrm{spores} / \mathrm{ml}$ \\
\hline $\mathrm{r}($ Correlation coefficient $)$ & $=0.949($ Tabulated $\mathrm{r}=0.95)$ \\
\hline $\mathrm{P}\left(\right.$ probability of $\left.X^{2}\right)$ & $=0.69$ \\
\hline
\end{tabular}

Table (5): Selectivity ratio (SR) of B. bassiana against adult female mite $T$. urticae and the predator S. gilvifrons.

\begin{tabular}{cccc}
\hline & T. urticae & S. gilvifrons & $($ SR $)$ \\
\hline LC50 & $2.7019 \times 10^{5}$ & $2.208 \times 10^{12}$ & $\approx 7$ fold \\
\hline LC90 & $6.1987 \times 10^{10}$ & $2.839 \times 10^{17}$ & $\approx 7$ fold \\
\hline S.R.=LC50 or 90 of No. target / LC50 or 90 of target.
\end{tabular}

increasing rate for both adult females of the mite $T$. urticae and the predator $S$. gilvifrons infested by $B$. bassiana was correlated with increasing concentration and time of infestation. There were latent periods between infestation and mortality achievement in both tested organisms noted after about 8 days. The $\mathrm{LC}_{50}$ value of $B$. bassiana was $2.702 \times 10^{5}$ spores $/ \mathrm{ml}$ after eight days from infestation, while the $\mathrm{LC}_{50}$ value of $2^{\text {nd }}$ larval instar of $S$. gilvifrons was $2.208 \times 10^{12}$ spores $/ \mathrm{ml}$ after 8 days of infestation. Such selective toxicity was also noted at $\mathrm{LC}_{90}$ level as the values were $6.1987 \times 10^{10}$ and $2.839 \times 10^{17}$ for adult females of T. urticae and $2^{\text {nd }}$ instar larval stage of $S$. gilvifrons. These results show that the entomopathogenic fungi $B$. bassiana enhanced selective toxicity power between the adult females of T. urticae and $2^{\text {nd }}$ instar larva of S. gilvifrons which recorded about 7 folds after 8 days from infestation.

\section{Disease Symptoms:}

There was experimental evidence, particularly which presented by Schaerffenberg (1957), showed that $B$. bassiana, like many other entomogenous fungi, kills its insect host by the action of hyphae that germinate from spores, penetrate the exocuticle, and subsequently invade and destroy the internal tissues.

Shigeo (1978) reported that a toxin named bassianolide has been isolated from the $B$. bassiana bodies which accounted for the lethality and toxicity accompanying the atonic symptom detected in the dead silkworm, Bombyx mori, pupae infected with $B$. bassiana. This finding is completely in agreement with that of Yousri (1994). The adult females of T. urticae were probably infected and killed by the same way. At the time of death, infected mites become dark in colour, unlike their usual appearance. About $48 \mathrm{~h}$. after death and incubation at $24^{\circ} \mathrm{C}$ and approximately $100 \% \mathrm{RH}$, using the selective medium their colour changed to gray-white and the body surface partially filled with fungal mycelium, after further $48 \mathrm{~h}$., aerial mycelium appeared and gradually covered the whole body surface. Sporulation on the surface of the cadaver mites occurred on $9^{\text {th }}$ day after death.

\section{REFERENCES}

Abbott, W. S. 1925. A method for computing the effectiveness of an insecticide. J. Econ. Entomol. 18: 265-267.

Alves, S. B.; Rossi, L. S. and Lopes, R. B. 2002. Beauveria bassiana yeast phase on agar medium and its pathogenicity against Diatraea saccharalis (Lepidoptera: Cramidae) and 
Tetranychus urticae (Acari: Tetranychidae). J. Invertebrate Patholoy 81 (2): 70-77.

Bassi, A. 1835. Del mal segno calcinaccio o moscardino, mallatia che affligge I bachi da seta e sul modo di liberane le bigattaie anche le piu infestate.Parte I: Teoria. Orcesi, Lodi, pp. i-IX, 1-67.

Congdon, B. D.; Shank, C. H. and Antonelli, A. L. 1993. Population interaction between Stethorus punctum picips (Coleoptera: Coccinellidae) and Tetranychus urticae koch (Acari: Tetranychidae) in raspberries at low predator and prey densities. Environ. Entomol. 22:1303-1307.

De Bach, Paul. 1964. Biological control of insect pests and weeds. Chapman and Hall LTD, II New Fetter lane, London E.C. 4, 844 pp.

Dresner, E. 1949. Use of fungi for microbial control of mites and ticks. In "Microbial Control of Insects and Mites" (H.D. Burges and N.W. Hussey, eds.). Academic Press, London and New York. $117 \mathrm{pp}$

Dunn, P. H., and Mac Leod, B. J. 1963. The potential of Beauveria bassiana (Balsamo) Vuiillermin as a microbial insecticide. J. Insect Pathol. 5: 451-459.

El-Basha, Nesrin A. and Mandour, N. S. 2005. The predation of Stethorus gilivifrons (Mulsant) (Coleoptera: Coccinellidae) on different egg densities of Tetranychus urticae (Koch) (Acari: Tetranychidae). Agric. Res. J. Suez Canal Univ. (5):109-114

El-Kady, G. A.; El-Sharabasy, H. M.; Mahmoud, M. F. and Bahgat, I. M. 2007. Toxicity of two potential bio-insecticides against moveable stages of Tetranychus urticae Koch. J. Applied Scinees Research 3 (11): 1315-1319.

Finney, D. J. 1971. Probit analysis - a statistical treatment of the sigmoid response Curve. Cambridge University Press $333 \mathrm{pp}$.

Helle, W. and Sabelis, M. W. 1985. Spider Mites, their biology, Natural Enemies and Control A; World Ceop Pests 1A Elsevier, Amsterdam, 21-24.

Kenneth R.; Wall G.; Olmert Y. and Halprin J. 1971. A list of entomopathogenic fungi of Israel. Isr. J. Agric. Res., 21: 63-66.

Leatherdale, D. 1970. The arthropode hosts of entomogenous fungi in Britain. Entomophaga, $15,419-435$.

Raudonis, L. 2006. Comparative toxicity of spirodiclofen and lambdacihalotrin to Tetranychus urticae, Tarsonemus pallidus and predatory mite Amblyseius andersoni in a strawberry site under field conditions. Agronomy Research 4 (Special issua), 317-322.

Roberts, D. W., and Yendol, W. G. 1971. Use of fungi for microbial control of insects. In "Microbial control of insects and mites" (H. D. Burges and N. W., eds.) Academic Press, London and New York. $274 \mathrm{pp}$.

Rott, A. S. and Ponsomby, D. G. 2000. The effect of temperature, relative humidity and host plant on the behavior of Stethorus punctillum as a predator of the two-spotted spider mite Tetranychus urticae. Bio Contol 45:155-164.

Sarhan, A. A.; Shoukry, A. and Ahmed, S. A. 1989a. Biological studies on Stethorus gilvifrons (Mulsant) a predator of Tetranychus urticae (Koch) in Egypt. Proc. $3^{\text {rd }}$ National Conf. of Pest \& Plant Disease of Vegetable \& Fruits in Egypt and Arab Countries, Ismailia, Egypt, 1: 124-139.

Sarhan, A. A., Shoukry, A. and Ahmed, S. A. 1989 b: Feeding capacity of the predator Stethorus gilvifrons (Mulsant) and effect of its prey, Tetranychus urticae (Koch) on its post embryonic stages. Proceed $3^{\text {rd }}$ Nat. Confers of Pest \& Plant Disease of Vegetable \& Fruits in Egypt and Arab Countries, Ismailia, Egypt, 1: 140-148.

Schaerffenberg, B. 1957. Infektion und entwicklungsverlauf des insektentolendon plizes Beauveria bassiana (Vuiil.) Link. Z. Angew. Entomol., 41: 395-401.

Shigeo, M. 1978. Presence of toxic substance in fungus bodies of the entomopathogenic fungi, Beauveria bassiana and Verticillium lecanii. Appl. Ent. Zool., 13 (2): 97-102.

Tanada, Y. 1953. Applied insect pathology in Hawaii. Hawaii Farm Sci., 2: 7-8.

Vanninen, I. and H. Hokkanen. 1988. Effect of pesticides on four species of entomopathogenic fungi in vitro. Annales Agr. Fenniae, 27: 345-353.

Yevlakhova, A. A. and Shvetsova, O. I. 1965. Basic aspects of research on microbiological control of insect pests. (with English translation). Entomol. Rev. (USSR) 44: 423-426.

Yousri, H. M. 1994. Laboratory evaluation of Beauveria bassiana (Balsamo) Vuiil. as a pathogen of adult female stage of the two spotted spider mite Tetranychus urticae koch. Egypt, J. Appl. Sci., 9 (2): 380-387.

Yousri, H. M. 1999. Effect of certain unconventional acaricides against the two spotted spider mite Tetranychus urticae Koch on eggplants. Egypt, J. Appl. Sci., 14 (7): 576-581. 